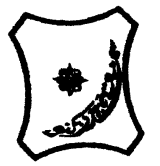

Bayero Journal of Pure and Applied Sciences, 11(1): 179 - 182

Received: January, 2018

Accepted: May, 2018

ISSN $2006-6996$

\title{
RESPONSE OF SOME CYANOBACTERIAL SPECIES FOR ADSORPTION OF MANGANESE, COBALT AND NICKEL FROM UNTREATED TANNERY EFFLUENT IN KANO, NIGERIA
}

\author{
Ado, G., Haruna, H, and Indabawa, I.I. \\ Department of Plant Biology, Faculty of Life Sciences, Bayero University, Kano. \\ garbado05@gmail.com (08036350343)
}

\section{ABSTRACT}

The research was conducted to monitor the performance of some endogenous species of Cyanobacteria for the adsorption of Manganese (Mn), Cobalt (Co) and Nickel (Ni) from untreated effluents of Fata Tanning Limited (FTL) in Kano between July 2014-June, 2015. Primary field investigation and laboratory analysis were the main sources of data in the study. The study areas were divided into three strata within which samples were collected using stratified sampling techniques from a depth of 0-30 cm. The study assessed the adsorption capacity of some heavy metals namely; Mn., Co. and Ni using Atomic Absorbance Spectrophotometer (AAS). Indigenous cyanobacteria species identified and isolated were Anabaena variabilis, Lyngbya majusculata and Oscillatoria princeps using microscopy and standard phycological chart as described by Komerak and Anagnostidis, (1989). Bioremediation Bioassay was conducted to evaluate the adsorption capacity of the isolated organisms. The results showed that, tested organisms reduced the concentration level of heavy metals in the effluents to the standard limit proposed by FEPA (1997), WHO (1999) and (ICLARM, 1997). Anabaen was found to remove more Ni (4.13\%) followed by Lyngbya (3.78\%) all at 9 weeks after inoculation. Higher concentration of Mn (3.85\%) and Co of (4.04\%) were removed by Lyngbya and Oscillatoria at 9 weeks after inoculation. These findings indicated that all the tested organisms possessed great potential in removing heavy metals from untreated tannery effluents. These findings also showed that adsorption of heavy metals by the tested organisms increased with time from 3-9 weeks of inoculation and adsorption was significantly higher at 9 weeks after inoculation and some decline at 9 WAI

Keywords; Cyanobacterial species, Effluent, FTL and Heavy metals

\section{INTRODUCTION}

Release of heavy metal in large amounts from industries into and across Nigeria has resulted in many problems for both human health and aquatic ecosystem (Inthorn et al., 1996). Thus everyone is being exposed to contamination from past and present industrial practices, emission in natural resources (air, water and soil) even in the most remote regions. The risk to human and environmental health is rising and there is evidence that this cocktail of pollutants is a contributor to the global epidemic of cancer, and other degenerative diseases (Puschenreite et al., 2005). Once the metals enter in to the soil, they are strongly held by soil particles and there is little removal by plant uptake or movement down the soil profile. In low and medium contaminated soils, concentration of metals in crops is mostly not high enough to cause acute toxicity, but in the long run, it may cause chronic damage to human/animal health (Puschenreite, et al., 2005). The challenge is to develop innovative and cost-effective solutions to decontaminate polluted environments, to make them safe for human habitation and consumption, and to protect the functioning of the ecosystems which support life. Bioremediation is the use of biological interventions of biodiversity for mitigation (complete elimination) of the noxious effects caused by environmental pollutants in a given site (Blanco, 2000). Bioremediation has been successfully applied for cleanup of soil, surface water, ground water, sediments and ecosystem restoration (Blanco, 2000). Bioremediation is generally contributed to the fate of hazardous wastes and can be used to remove these unwanted compounds from the biosphere (Ma et al., 2011; Schroeder and Schwitzguebe, 2004).

Heavy metals enter into our environment from both natural and anthropogenic sources such as processing industries and incomplete combustion of burning fuel (Duffus, 2002). Manufacturing and distribution of products such as batteries, perfumes, soap, deodorant, metal scrap, textile, plastics, tanneries and garbage have resulted in the generation of a huge volume of waste. The composition of these wastes is an important source of environmental pollution, contributing to the heavy metal load in effluent (Haliru et al., 2014). All heavy metals are toxic in effluent in concentrations above normal level. Addition of heavy metals to effluent may affect microbial proliferation and enzymatic activities, leading to a decrease in the rates of the biochemical process in the soil environment. Worldwide increasing level of industrialization and urbanization has lead to environmental pollution (Filazi et al., 2003; Businelli et. al, 2009). 


\section{Bajopas Volume 11 Number 1 June, 2018 MATERIALS AND METHODS \\ Study Area}

Kano is a city in Northern Nigeria $\left(11^{\circ} 59.981 \mathrm{~N}, 008^{\circ}\right.$ 31. 491E) which is the largest city in Nigeria with population density of 2.66 per hectare (UNEP, 2004). Kano is home to $70 \%$ of Nigerian tanneries. The study was carried out on effluents from Fata Tanning Limited (ATM) $\left(11^{\circ} 88.571 \mathrm{~N}, 008^{\circ} 48.325 \mathrm{E}\right)$ located at Challawa Industrial Area in Kumbotso Local Government in Kano State. Effluents were sampled on monthly basis from July, 2014 to June, 2015.

Determination of Heavy Metals of the Effluent.

Metals contents were determined prior to inoculation of isolated Algal species. All collected samples were placed inside sampling box containing ice prior to analysis in the Laboratory. Concentrations of three heavy metals ( $\mathrm{Fe}, \mathrm{Cu}$ and $\mathrm{Hg}$, ) were determined using AAS VGP 210 Model. The instrument was set up at wave lengths specific to each element to be analyzed. Five milliliter $(5 \mathrm{ml})$ of the samples was used one after the other without delay between them. Distilled deionized water was added frequently between each reading. Readings of the absorbance were obtained by observing the steady galvanometer readings in 1-2 minutes. Determination of each sample was carried out in triplicate to get representative results.

\section{Sample Concentration}

In the Laboratory, $10 \mathrm{mls}$ of the preserved effluent samples were centrifuged in a graduated tube at 1500 rpm for 30 minutes, using a centrifuge machine (Model Merlin 502-000). One $\mathrm{ml}$ of sample concentrate (sediment) was pipette on a slide for identification of algal species.

\section{Isolation and Identification of Algal species}

Pure culture of Algal species was obtained by Capillary Pipette Isolation method as described by (Bold, 1972). This involves putting several droplets of sample on a slide and covered with the cover slip using a capillary pipette. The drops were examined under microscope; Anabaena, Lyngbya and Spirulina among others were obtained. The drop was removed with a sterile capillary pipette and transferred into a prepared (BG 11) medium and incubated in the bioreactor (Kadiri and Opute, 2013) at $24{ }^{\circ} \mathrm{C}$ for $48 \mathrm{hr}$. Algal cells were viewed using a light microscope attached to a camera, identified using standard Phycological Keys and morphological criteria as described by Palmer, (1980); Komerak and Anagnostidis, (1989).

\section{Algal culture and Purification}

Blue Green-(BG 11) modified medium was used. Three genera of algae identified (Anabaena. Lyngbya and Oscillatoria) were cultured in $50 \mathrm{mls}$ BG 11 media and incubated for three weeks in a photo bioreactor (PBR) in which the specimen grown. It is a closed system incorporates light and all required essential nutrients. The organisms were harvested when the biomass reached exponential/log phase. The cultures were treated using a combination of antibiotics such as Chloramphenicol $25 \mathrm{mg} / \mathrm{L}$, Penicillin $10 \mathrm{mg} / \mathrm{L}$ and Griseofulvin $50 \mathrm{mg} / \mathrm{L}$. Therefore, the ratio was $5 \mathrm{mg}$ : 2mg: $10 \mathrm{mg}$ of Chloramphenicol, Penicillin and Griscofulvin to $200 \mathrm{mls}$ of media as described by Kaul and Gautan, (2000).

\section{Bioremediation Bioassay}

Twenty Seven Conical Flasks were prepared in which a single flask was filled with $200 \mathrm{ml}$ of effluent and inoculated with a three week dense individual algal suspension as described by Shahidulrahman, (2004). The set up was replicated three times and allowed until 3Weeks, 6Weeks and 9Weeks. Adsorption capacity of algal species was estimated using the following formula $\frac{w c-c}{\mathrm{c}} \times 100$ (Kadiri and Opute, 2013). Where (wc) is the final concentration of heavy metal in the algal species after inoculation for time (t) and $(C)$ is the initial concentration of heavy metal in algal species before inoculation.

\section{RESULTS AND DISCUSSION}

The polluting metals such as $\mathrm{Zn}, \mathrm{Cd}, \mathrm{Cu}, \mathrm{Cr}$ and $\mathrm{Ni}$ have high atomic number with a density greater than $5 \mathrm{~g} / \mathrm{cm}^{3}$ or $6 \mathrm{~g} / \mathrm{cm}^{3}$ (Bellamy, 2007; Wild, 1996). These metals are the cause of environmental pollution from a number of sources including lead in petrol, industrial effluents and leaching of metal ions from soil into the water bodies (Lane et al., 2005). Aquatic organisms require varying amount of heavy metals such as $\mathrm{Fe}$, $\mathrm{Zn}$ and $\mathrm{Cu}$ for metabolic activities, but excessive level can be detrimental to the organisms hence the term "trace" (Lane et al., 2005). Current study revealed the heavy metals adsorption capacity of some algal species. Awasthi and Rai (2004) reported that trace level of heavy metals in the body of lower plant organism boost their yield and growth. Similarly, algae use metals as part of nutrients, for instances they use iron during photosynthesis while chromium is use for metabolism (Zang et al., 1996).

Cobalt adsorption capacity of the cyanobactria species from FTL effluent is shown in Table 1 . The results indicated that cobalt adsorption of the tested organisms remained low at 3WAI (Weeks After Inoculation). When incubation period was extended to 9 weeks, adsorption was significantly increased to (4.04\%) in Oscillatoria. For Anabaena and Lyngbya, adsorption were also significantly $(P<0.05)$ high at 9WAI. Study on the use of algae for removing heavy metals ions from waste water by Mehta and Gaur (2005) revealed similar observation where comparative analysis between algae and Arthrobacter species showed that the ability of Arthrobacter globiformis to remove Gold from the solution was better than that of Spirulina platensis and they attributed the ability of algae to remove the gold to fact that the cell wall consists of a variety of polysaccharides and protein and hence offer a number of active sites capable to bind metal ions. However, difference in the cell wall composition of different groups of algae causes significant difference in the type and amount of metal ion binding to them (Mehta and Gaur, 2005). This study also agrees with finding of Kumar and Gaur, (2011) who stated that the genus of Lyngbya and gloeocapsa removed chromium from tanneries discharge and used it for metabolism at 12 weeks after their inoculation than 6 weeks after inoculation. 
Bajopas Volume 11 Number 1 June, 2018

The result of Manganese adsorption capacity by some algal species from FTL is presented in Table 2 . The result indicated that Lyngbya adsorbed the highest values of $\mathrm{Mn}(3.85 \%)$ at 9WAI. Anabaena and Oscillatoria recorded $3.44 \%$ and $3.39 \%$ respectively. $\mathrm{Mn}$ is an essential element for all known living organisms including humans at low doses of intake. But at much higher doses, toxic effects can occur. Manganese can enter the environment through releases from tannery industries that make use of $\mathrm{Mn}$ compounds (ATSDR, 2004). This work agrees with the work of Solisio et al., (2006) who reported the considerable potential adsorption of many metals by Spirulina platensis.

Nickel adsorption capacity of the different species of cyanobacteria from the Fata Tanning Limited (FTL) is recorded in Table 3. The result showed that Anabaena had the highest $\mathrm{Ni}$ adsorption capacity of $4.13 \%$ at 9WAI. Lyngbya recorded $3.78 \%$ at 9 WAI while. Oscillatoria had $3.29 \%$ all in 9WAI . This finding is in conformity with the report of Semyalo, (2009) who stated that significant milligrams of $\mathrm{Ni}$ were absorbed by Chlorella vulgaris in tannery effluent in the sixth week of period of inoculation.

Table 1 : Cobalt Adsorption Capacity (\%) of Some Algal Species from FTL Effluents

$\begin{array}{lll}\text { Organisms } & \text { 3WAI } & \text { GWAI }\end{array}$

\begin{tabular}{llll}
\hline Anabaena & $3.02 \mathrm{c}$ & $3.16 \mathrm{~b}$ & $3.59 \mathrm{a}$ \\
Lyngbya & $2.12 \mathrm{c}$ & $2.94 \mathrm{~b}$ & $3.17 \mathrm{a}$ \\
Oscillatoria & $3.64 \mathrm{c}$ & $3.87 \mathrm{~b}$ & $4.04 \mathrm{a}$ \\
SE & & $\mathbf{1 . 0 6}$ & \\
\hline
\end{tabular}

Means along columns with different letters differ significantly $(\mathrm{P}<0.05)$. Keys: WAI: Weeks After Inoculation, FTL : Fata Tanning Limited, SE: Standard Error

Table 2: Manganese Adsorption Capacity (\%) of Some Algal Species from FTL Effluents

Organisms

3WAI GWAI 9WAI

\begin{tabular}{llll}
\hline Anabaena & $1.70 \mathrm{c}$ & $2.61 \mathrm{~b}$ & $3.44 \mathrm{a}$ \\
Lyngbya & $2.36 \mathrm{c}$ & $3.52 \mathrm{~b}$ & $3.85 \mathrm{a}$ \\
Oscillatoria & $2.18 \mathrm{c}$ & $3.20 \mathrm{~b}$ & $3.39 \mathrm{a}$ \\
SE & & $\mathbf{1 . 2 9}$ &
\end{tabular}

Means along columns with different letters differ significantly $(\mathrm{P}<0.05)$. Keys: WAI: Weeks After Inoculation, FTL : Fata Tanning Limited, SE: Standard Error

Table 3: Nickel Adsorption Capacity (\%) of Some Algal Species from FTL Effluents

\begin{tabular}{llll}
\hline Organisms & 3WAI & 6WAI & 9WAI \\
\hline Anabaena & $3.59 \mathrm{c}$ & $3.91 \mathrm{~b}$ & $4.13 \mathrm{a}$ \\
Lyngbya & $2.60 \mathrm{c}$ & $3.62 \mathrm{~b}$ & $3.78 \mathrm{a}$ \\
Oscillatoria & $2.31 \mathrm{c}$ & $3.07 \mathrm{~b}$ & $3.29 \mathrm{a}$ \\
SE & & $\mathbf{0 . 5 5}$ & \\
\hline
\end{tabular}

Means along columns with different letters differ significantly $(\mathrm{P}<0.05)$. Keys: WAI: Weeks After Inoculation, FTL : Fata Tanning Limited, SE: Standard Error

\section{Conclusion}

The overall findings of the study revealed the adsorption capacity of some algal species, the test organisms were found to reduce the level of heavy metal concentrations from the effluents of Fata Tanning Limited (FTL) to the recommended limit agreed by World Health Organization (WHO) and Federal Environmental Protection Agency (FEPA). All the three test organisms adsorbed great amount of $\mathrm{Ni}$ while Lyngbya was found to sequestered large percentage of $\mathrm{Mn}$. 


\section{Bajopas Volume 11 Number 1 June, 2018 \\ Contribution of Authors}

1. Garba Ado and Hajara Haruna ;- were responsible for carrying out the experiment.

2. Isyaku Ibrahim Indabawa;- responsible for the statistical analysis of the work

Conflict of interest;- Nil

\section{REFERENCES}

Abidemi, O.O. (2013). Accumulation and Contamination of Heavy Metals in Soil and Vegetation from Industrial Area of Ikirun, Osun State, Nigeria, Global Journal of Pure and Applied Chemistry Research, 1 (1): 25-34

ATSDR (2004). Toxicological profile for $\mathrm{Cu}$. US Dept. of Health and Human Services. Public Health Service Agency for Toxic Substance and Diseases Registry, US.

ATSDR, (2008). Agency for Toxic Substances and Disease Registry.Tox FAQs Chemical Fact Sheets, www.atsdr.cdc.gov/toxfaq.html r 20/09/2011

Awasthi, M. and Rai, L.C. (2004). Adsorption of Nickel, Zink and Cadmium by Immobilized Green Algae and Cyanobacteria: A Comparative Study. Annals of Microbiology, 54:257-267.

Bellamy. P (2007): Academic's Dictionary of Environment, $1^{\text {st }}$ edition, Academic Publishers, India. Pp 36-49

Blanco, A., (2000). Immobilization of onviable Cynobacteria and their Use for heavy metal Adsoption from Water in Environmental Biotechnology and Cleaner Bioprocesses. Edited by Oluguin E. J, Snchez and Hermandex E (Philadeiphia, Taylor and Amp, Francis. 135).

Bold F. A.(1972). Algal activities and phytoplankton ecology. Univ. wisconsis press. Pp 63-66

Businelli, D., Massaccesi, L. and Onofri, A. (2009). Evaluation of Lead and Nickel Mobility to Ground Water in Calcareous Urban Soils of Ancona, Italy, Water, Air and Soil Pollution Journal, 201:185-193

Duffus. J. H. (2002). "Heavy metals" - a meaningless term, Pure Applied Chemistry, (74): 793-807

Federal Environmental Protection Agency, FEPA (1997): National Environmental Protection Effluent Limitation) Regulation of 1991 . Federal Environmental Protection Agency, Lagos, Nigeria. Ref. S. 1-8

Filazi, A., Baskaya, R. K. C. and Hismiogullari, S .E. (2003). Metal Concentration in tissues of theBlack Sea Fish Mugil Auratus from Sinop-Iclimari, Turkey, Human Experiment and Toxicology, 22: 85-87

Haliru, A. H., Law, P. L. and Suhaiza, S. O. (2014). Heavy metals concentration levels in soil

at Lake Geriyo irrigation site, Yola, Adamawa state, Northern Eastern Nigeria, International Journal of Environmental Monitori and Analysis, 2 (2): 106 111

International Center for Living Aquatic Research and Management, ICLARM (1997): ABEE LengthWeight, Software Coefficient, Version 1.0. ICLARM, MC, Makati, Philippines.

Inthorn, D., Nagasase, H., Isaji, Y., Hirata, K. and Miyamoto, K. (1996): Removal of Cadmium from aqeuos solution by the filamentouse cyanobacterium. Tolypothrix tenuis. Journal Ferment. Bioengineering. 82:580-584

Kadiri, M.O and Opute, F.I. (2013). Phytoplankton Algae of Nigeria. Mindex Publishing (1) Pp 43, 69-70

Kaul, S. N. and Gautam, A. (2000): Water and wastewater analysis. Daya Publishing House, Delhi, India. Pp: 3-250

Komerak, J. and Anagnostidis, K. (1989): Modern Approach to Classification System of Cyanophytes. Arc.
Hydrobiol. Suppl. 71 Algological Studies. 38/39, 291-302

Kumar, K., Devi, S.S., Krishnamurthi, K., Gampawar, S., Mishra, N., Pandya, G. H. And

Chakrabarti, T. (2005). Decolorization, biodegradation and detoxification of benzidine based azo dyes. Bioresource Technology 1-7.

Kumar. D. \& Gaur. J.P. (2011). Metal biosorption by two cyanobacterial mats in relation to $\mathrm{pH}$, biomass concentration, pretrealment and reuse. Biuresuur. Technol,102; 2529-2535.

Lane, T. W., Saito, M. A., George, G.N., Pickering, I. J., Prince, R. C. M. and François M. M. (2005). "A cadmium enzyme from a marine diatom" (PDF). Nature 435 (42): 42.

Ma, Y., Prasad, M.V., Rajkumar, M., and Freitas, H. (2011). Plant growth promoting rhizobacteria and endophytes accelerate phytoremediation of metalliferous soils. Biotechnology Advances 29: 248-258.

Mehta,S.K. and Gaur, J.P. (2005). Use of algae in removing of heavy metals ion from wastewater, progress and prospect. Crit. Rev. Biotechnology, 25:113152

Palmer, C.M. (1980): Algae and Water Pollittion.CzstieHouse Publication, England. Pp 123

Puschenreite, M., Horak, O., Friesl, W. and Hartl, W. (2005). Low-cost agricultural measures to reduce heavy metal transfer into the food chain-a review, Plant and Soil Environment, 1: 1-11

Schroeder, and P Schwitzguebel, J.P.. (2004). New cost action launched: Phytotechnologies to promote sustainable land use and improve food safety, Journal of Soils and Sediments 4 (3), 205.

Semyalo, R. P. (2009). The effects of cyanobacteria on the growth, survival, and behaviour of a tropical fish (Nile Tilapia) and zooplankton (Daphnia lumholtzi). Ph.D. Thesis, University of Bergen, Norway. PP 28

Shahidul-Rahman, MD; Aminul Islam, MD; Shahidul Haque, and Abdulkarim MD (2004): Effect of planting date and gibberellic acid on the growth and yield of garlic. Asian journal of plant sciences 3(3): 344352

Solisio, C., Lodi, A., Torre, P., Converti. A. and Del. M. B. (2006) Copper Removal by Dry and Re-hydrated Biomass of SPirulinaPlatensis.Bioresour Technology, 97 1756-1760.

United Nation Environment Programme UNEP, (2004): Draft Technical Guidelines on the Environmentally Sound Recycling/Reclamation of Metals and Metals Compounds (R4). Conference of the Parties to the Basel Convention on the Control of Transboundary Movement of Hazardous Waste and their Disposal. Basel Convention, $11^{\text {th }}$ August, 2004. www.unep..org

WHO (1999): Limits for Effluents Discharged into Surface water. World Health Organization, Geneva, $\mathrm{CH}$. Pp 46-51

Wild, A. (1996): Soil and Environment: An introduction. Cambridge University Press, Cambridge, Pp 290

Zhang, X. G. (1996). Corrosion and Electrochemistry of Zinc. Springer. Pg. 93. ISBN 0-306-45334-7. 